\title{
Genetic Uniformity of the MSXJ papaya hybrid (Carica papaya L.) during Micropropagation
}

\section{Ramírez-Hernández, Dulce M. ${ }^{1}$; Castañeda-Castro, Odón²; Galindo-Tovar, María E. ${ }^{1 *}$; Solano Rodríguez, Luis A. ${ }^{3}$; Leyva Ovalle, Otto R. ${ }^{1}$; Pastelín Solano, Miriam C. ${ }^{2}$}

\author{
${ }^{1}$ Universidad Veracruzana, Amatlán de los Reyes, Veracruz, México. ${ }^{2}$ Universidad Veracruzana, \\ Orizaba, Veracruz, México. ${ }^{3}$ Producción Genética Agropecuaria de México (PROGAMEX). \\ Córdoba, Veracruz, México.
}

*Corresponding author: megalindo@uv. $m x$

\begin{abstract}
Objective: To analyze the genetic uniformity of MSXJ hybrid papaya in vitro plants, obtained by direct organogenesis. Design/Methodology/Approach: The MSXJ papaya hybrid demonstrates quality characteristics for the national and exports market. In vitro culture of plant tissues represents a useful tool for their multiplication and conservation, but somaclonal variation can diminish their genetic and agronomic uniformity. In order to analyze the genetic uniformity of in vitro plants of this hybrid, ten ISSR primers were used for in vitro plants micropropagated during nine subcultures. DNA was extracted using the CTAB method. Data were analyzed using the program PopGene v 1.3.1.

Results: Eighty-five loci of 200 to up to 2000 pb were generated, with 37 polymorphic loci. In the cluster analysis, three groups were observed which separate subculture one, subcultures two to eight, and subculture nine; the Gst value of 0.87 indicated genetic uniformity as far as subculture eight.

Study Limitations/Implications: Papaya is one of the most important tropical fruits worldwide; however, these plants need to be healthy and genetically uniform to guarantee commercial success. In vitro propagation allows obtaining healthy and uniform plants, but it is necessary to study genetic uniformity during their micropropagation.

Findings/Conclusions: The in vitro multiplication of the MSXJ papaya hybrid permitted the regeneration of vigorous plants in $30 \mathrm{~d}$. Molecular profiles indicate that as far as subculture eight, there is genetic uniformity. As such, no more than eight subcultures are recommended during micropropagation
\end{abstract}

Keywords: In vitro plants, genetic uniformity, papaya, ISSR

\section{INTRODUCTION}

\section{Papaya}

(Carica papaya L.), along with mango (Mangifera indica L.), avocado (Persea americana L.) and pineapple (Ananas comosus (L.) Merr), is one of four tropical fruits with the highest volume in exports. Globally, it is among the most well-known and consumed fruits (Altendorf, 2018). It is cultivated extensively in more than 60 countries in the tropics and subtropics (FAO, 2017). In 2017, Mexico positioned itself as the third top producer in the world and the fifth top exporter with 961,768 tons (SIAP, 2018).

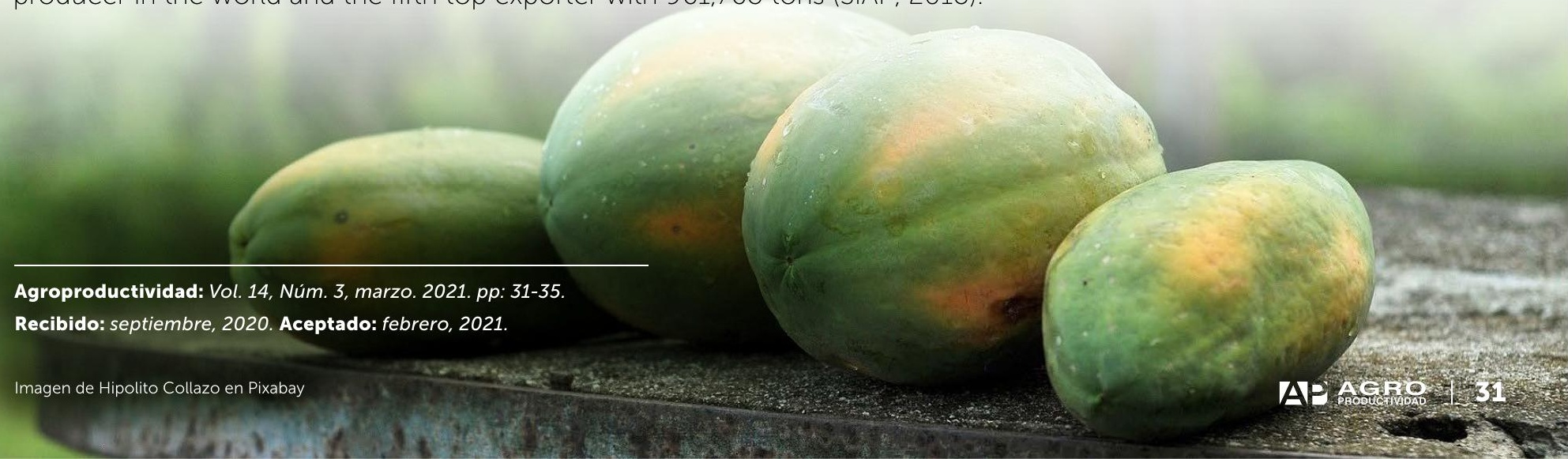


The cultivation of papaya faces significant problems, such as the ringspot virus (Valencia et al., 2017), which affects its production and productivity (Vincent et al., 2019). For this reason, the development of cultivars with better characteristics is of great importance. The MSXJ papaya hybrid developed in the Experimental Camp of Huimanguillo, Tabasco (INIFAP) demonstrates quality characteristics for the national and exports market: it has red flesh and is tolerant to high temperatures during its flowering and fruiting stage (Mirafuentes and Santamaría, 2014). However, efficient propagation methods are needed to ensure its genetic characteristics, sex, safety, and agronomic uniformity. One of these methods is in vitro cultivation, which is useful for obtaining plants with high genetic and phytosanitary quality, as well as facilitating their use in plant-breeding efforts (Olivera, 2009). In the case of the papaya, there are various reports on its in vitro propagation (Ascencio et al., 2008; Setargie et al., 2015; Teixeira, 2016; Bindu and Bindu, 2017; Solórzano et al., 2018; Chaudhary and Prakash, 2019). Posada et al. (2004) reported a propagation protocol using apexes and Solis et al. (2011) using meristems. Recently, Al-Shara et al. (2018) published a review of the methods and limitations in papaya micropropagation where they refer to the difficulties they have found in commercial in vitro propagation of papaya; among these, they cite the small margin of certainty in reproducing and ensuring the production of healthy plants without genetic changes. Regarding this, it is necessary to confirm the genetic uniformity of the plants obtained using in vitro cultivation techniques (Posada, 2005). Genetic uniformity studies constitute a valid and fast technique for the detection of variability, since it allows distinguishing genotypes (Dávila and Castillo, 2007). Genetic markers can be successfully employed to search for differences in the expression patterns between cultivars, varieties, and plants. The ISSR markers are dominant and highly reproducible, therefore very useful for DNA profiling (González and Aguirre, 2007). Thus, the genetic uniformity of in vitro plants of the MSXJ papaya hybrid obtained via direct organogenesis was analyzed using ten ISSR primers during nine subcultures.

\section{MATERIALS AND METHODOLOGY}

The in vitro plants used were MSXJ papaya hybrids, developed in the Agricultural Biotechnology Laboratory of the Innovation and Development Park in the state Veracruz, located in the Monterrey Institute of Technology and Higher Education (ITESM) facilities. The in vitro plants were obtained from two hermaphrodite plants of the MSXJ hybrid, eight months old (P2 and P3). The samples were collected in Cotaxtla, Veracruz, Mexico. They were then regenerated via direct organogenesis from apical meristems, in a Murashige and Skoog (1962) basal medium at $100 \%$, supplemented with $100 \mathrm{mg} \mathrm{L}^{-1}$ of myo-inositol, $0.4 \mathrm{mg} \mathrm{L}^{-1}$ of thiamine, $30 \mathrm{~g} \mathrm{~L}^{-1}$ of sucrose, and $2.5 \mathrm{~g} \mathrm{~L}^{-1}$ Phytagel at $\mathrm{pH} 5.7 \pm 0.01$, with a photoperiod of $16 \mathrm{~h}$ light.

Multiplication of MSXJ hybrid. The in vitro plants were multiplied in the Agricultural Biotechnology Laboratory, and sub-cultured every $30 \mathrm{~d}$ nine times. For the in vitro multiplication of the MSXJ papaya hybrid, a Murashige and Skoog 100\% solid mineral salts medium was used, supplemented with adenine $10 \mathrm{mg} \mathrm{L}^{-1}$, thiamine 40 $m g L^{-1}$, myo-inositol $100 \mathrm{mg} \mathrm{L}^{-1}$, ascorbic acid 100 $m g L^{-1}$, sucrose $30 \mathrm{~g} \mathrm{~L}^{-1}$, and Phytagel $3 \mathrm{~g} \mathrm{~L}^{-1}$. The growth regulators used were naphthalene-acetic acid (NAA) $0.05 \mathrm{mg} \mathrm{L}^{-1}$, benzyl aminopurine (BAP) $0.5 \mathrm{mg}$ $\mathrm{L}^{-1}$, and gibberellic acid (GA3) $0.1 \mathrm{mg} \mathrm{L}^{-1}$ with a $\mathrm{pH}$ of 5.8. Jars with $250 \mathrm{~mL}$ capacity with $30 \mathrm{~mL}$ of culture medium were sterilized in an autoclave (Felisa) at $120^{\circ}$ $\mathrm{C}$ for $20 \mathrm{~min}$ and were left to rest for $24 \mathrm{~h}$ so that it could solidify.

Six shoots of MSXJ hybrid in vitro plants were placed in each jar with culture medium and kept at a controlled temperature $\left(24\right.$ to $26^{\circ} \mathrm{C}$ ) for $30 \mathrm{~d}$. After this time, each shoot was individualized and sub-cultured again in fresh culture medium. Additionally, remains of the gelling agent and callus that could accumulate on the seedlings were removed. A small sample of plant tissue was collected from each sub-culture of the in vitro plants and placed in an Eppendorf tube; the samples were frozen in a CRIOTEC freezer at $-50{ }^{\circ} \mathrm{C}$. This was carried out for each of the nine sub-cultures of the MSXJ hybrid micropropagated to analyze its uniformity.

Analysis of genetic uniformity. The genomic DNA extraction was done in the Teaching, Research and Services Laboratory (LADISER) of Plant Biotechnology and Cryobiology in the Molecular Biology department of the Faculty of Chemical Sciences at Universidad Veracruzana. The CTAB 2\% method was used (Murray and Thomson, 1980) with modifications. Two samples of in vitro plants were used for each one of the nine subcultures, resulting in a total of 18 samples. The purity and amount of DNA extracted from each of the samples was quantified and confirmed by UV spectrophotometry; 
purity was determined through optical density (OD 260 $\mathrm{nm} / \mathrm{OD} 280 \mathrm{~nm})$, and DNA integrity and quality were determined with $1.5 \%$ agarose gels.

DNA was amplified with the polymerase chain reaction (PCR) technique in an AXYGEN MAXYGENE ॥ thermocycler. A preliminary evaluation was carried out of 20 ISSR (Inter Simple Sequence Repeats) reported by Sudha et al. (2013). Only the primers with the greatest number of the clearest bands were selected. The reaction mixture final volume was fo $25 \mu \mathrm{L}$, which included $2 \mu \mathrm{L}$ of genomic DNA of the MSXJ hybrid, 5 $\mu L$ of $5 x$ My Taq Reaction Buffer, $2 \mu L$ of the primer, 0.2 $\mu \mathrm{L}$ of My Taq DNA Polymerase, and $15.8 \mu \mathrm{L}$ of ultrapure water. The DNA amplification program consisted of an initial denaturation at $94{ }^{\circ} \mathrm{C}$ for 5 min, followed by 45 one-minute denaturation cycles at a temperature of 52 ${ }^{\circ} \mathrm{C}$, extension at $72{ }^{\circ} \mathrm{C}$ for $2 \mathrm{~min}$, and final extension at 72 ${ }^{\circ} \mathrm{C}$ for $7 \mathrm{~min}$. The amplified products were separated by electrophoresis in $3 \%$ agarose gel using $2 \mu \mathrm{L}$ of Tri-color Buffer (5x DNA Loading), Gel Red Nucleic Acid Stain, and $8 \mu \mathrm{L}$ of each PCR sample; 3 $\mu \mathrm{L}$ of MPM Hyper Ladder $1 \mathrm{~Kb}$ molecular weight marker was used, suspended in TBE 1x (Tris/Borate/EDTA) at $90 \mathrm{~V}$ for $1: 30 \mathrm{~h}$. Finally, the amplified products were read in a UV transilluminator (Benchtop UV), capturing images for their subsequent analysis.

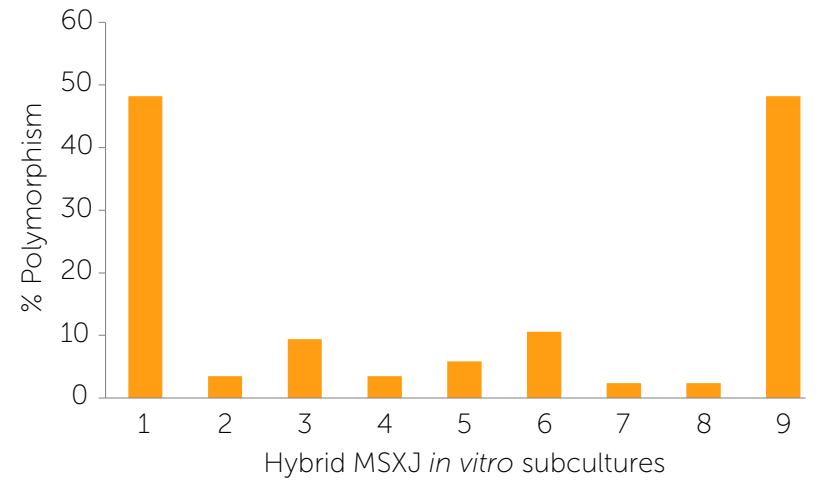

Figure 1. Percentaje of polymorphism for ten ISSR primers, in nine in vitro subcultures of Carica papaya MSXJ hybrid.

Molecular analysis. The first critical step to carry out a molecular study in plants is to obtain good-quality DNA (Castro-Gómez et al., 2012). The purity of extracted genomic DNA, determined by absorbency proportion at 260/280 nm, was 1.8 on average; which, according to Alejos-Velázquez (2014), is accepted as pure DNA. In addition, the integrity gels showed appropriate quality for their amplification with ISSR primers. The genomic DNA concentration of the 18 MSXJ hybrid samples was 30.9 $n g \mu L^{-1}$ on average, allowing the amplification of clear DNA bands.

Genetic uniformity analysis. Once the preliminary analysis of 20 ISSR primers for the genetic uniformity analysis of in vitro plants of the MSXJ hybrid micropropagated for nine subcultures was completed, ten ISSR primers were selected: UBC- 857-ACA CAC ACA CAC ACA CYC; T05- CGT TGT GTG TGT GTG TGT; ICL3- DBD ACA CAC ACA CAC ACA; UBC 841- GAG AGA GAG AGA GAG AYC; UBC 836- AGA GAG AGA GAG AYA; ICL16- GAG AGA GAG AGA GAG AYG; UBC 807- AGA GAG AGA GAG AGA GT; UBC 842GAG AGA GAG AGA GAG AG; UBC835- AGA GAG AGA GAG AGA GYC; UBC825ACA CAC ACA CAC ACA CT. These primers amplified 7 to 12 bands in 3\% agarose gel with an average of 8.5 bands (Figure 1)

The amplifications generated 85 loci with a molecular

Data analysis. The number of bands per primer were calculated, as well as the percentage of polymorphism, genetic identity and distance, according to Nei (1972). In addition, a cluster analysis was carried out with the unweighted pair group method with arithmetic mean (UPGMA) using the PopGene program v. 1.3.1.

\section{RESULTS AND DISCUSSION}

Micropropagation. The in vitro propagation protocol for the MSXJ papaya hybrid allowed obtaining vigorous seedlings free of diseases, with enough shoots for their multiplication. This coincides with that reported by Solis et al. (2011), since when propagating in vitro Carica papaya var. PTM-331 from apical meristems at $35 \mathrm{~d}$ they obtained large seedlings with a multiplication coefficient of 3.42 . weight of 200 to 2000 pb, and 37 polymorphic loci. The primers showing higher polymorphism were UBC841 with 12 bands, followed by UBC 807 with 11, and UBC 842 with six bands. The consistent and well-defined profiles of these ISSR primers showed that they can be used to determine the genetic uniformity of the MSXJ papaya hybrid during its in vitro micropropagation.

In the genetic uniformity analysis of the MSXJ papaya hybrid subcultures micropropagated in vitro, a $9.41 \%$ polymorphism was observed in subculture one. This polymorphism was greater than that of the next subcultures, and this can be explained by high heterozygosity due to the plant's cross-pollination. In subcultures two to eight, polymorphisms from 1.18 to 9.41 were present. The plants regenerated in these 
subcultures, though not identical, are considered similar amongst themselves since the Gst value was 0.87 , which indicates high genetic identity between subcultures. Because in vitro cultivation is a cloning technique, the variability in polymorphism in these subcultures is explained by the high heterozygosity that is reflected in variability among explants. This had already been reported by Rani and Raina (1998), who cited that the variability in the subcultures of plants regenerated using in vitro processes does not necessarily indicate that they are different from their phenotype. Additionally, López et al. (2006), after studying the genetic uniformity of papaya

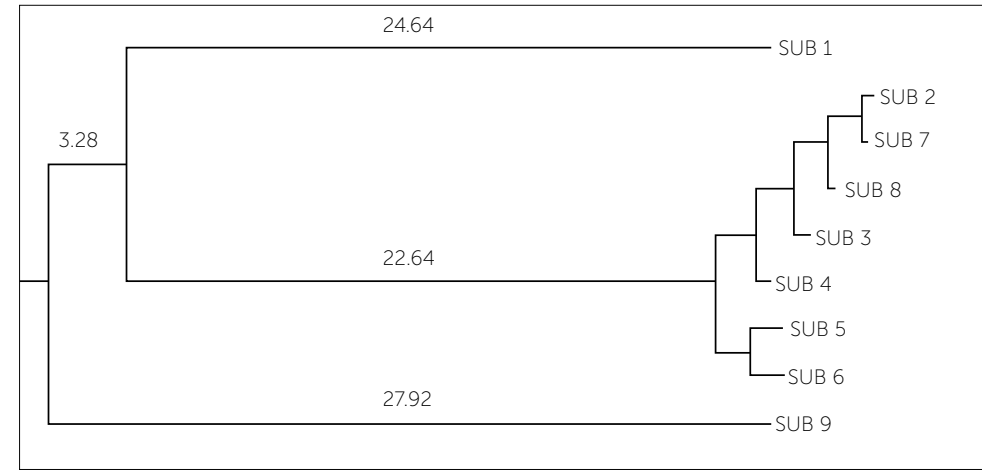

Figure 2. UPGMA dendrogram of nine in vitro subcultures for Carica papaya MSXJ hybrid, from DNA amplified with ISSR primers based on Nei's genetic distance. plants micropropagated from the proliferation of axillary buds and meristems, demonstrated that their morphological, agronomic, industrial, and molecular characteristics are stable.

The above is corroborated with the cluster analysis of the MSXJ papaya hybrid (Figure 2), stemming from the ISSR profiles obtained through Nei's (1972) similarity algorithm and the UPGMA grouping algorithm, which shows one group that includes subcultures two to eight and the separation of subcultures one and nine. Subculture one presented the highest values in genetic identity $(0.6342$ to 0.66001$)$ according to Nei. In subcultures two to eight it decreases slightly $(0.5122$ to 0.5983), and the lowest value was observed in subculture nine. Subculture nine presented the highest values in genetic distance (0.5158 a 0.6690) from the other subcultures, representing the greatest distance from subculture one. These data explain the separation of subcultures one and nine. In addition, the decrease of the genetic identity when increasing the number of subcultures coincides with that reported on the increase in frequency of the appearance of somaclonal variants as propagation cycles increase. This study recommends not exceeding eight subcultures, with the aim of minimizing the risk of genetic variability in the propagated material.

\section{CONCLUSIONS}

The in vitro multiplication of MSXJ hybrid papaya plants permitted the regeneration of vigorous plants in $30 \mathrm{~d}$, useful for establishing commercial orchards. The DNA obtained has sufficient quality to analyze genetic uniformity with ISSR primers in in vitro MSXJ hybrid papaya plants. The molecular profiles obtained indicate that genetic uniformity exists as far as the eighth subculture. Therefore, to reduce the risk of

genetic variability in the propagated material, it is recommended that no more than eight subcultures during micropropagation.

\section{REFERENCES}

Alejos-Velazquez, L.P., Aragón-Martínez, M.C. \& Cornejo-Romero, A. (2014). Extracción y Purificación de ADN. En: Cornejo-Romero, A., Serrato-Díaz, A.,Rendón-Aguilar, B., \& Rocha-Munive, M.G. (Eds.) Herramientas moleculares aplicadas en ecología: aspectos teóricos y prácticos. INECC-SEMARNAT. México.

Al-Shara, B., Rosna, M.T., \& Kamaludin, R. (2018). Biotechnological methods and limitations of micropropagation in papaya (Carica papaya L.) production: a review. J Animal and Plant Sciences 28(5) 1208-1226.

Altendorf, S. (2018). Perspectivas Mundiales de las Principales Frutas Tropicales. FAO. Disponible en: http://www.fao.org/fileadmin/ templates/est/COMM_MARKETS__ MONITORING/Tropical_ Fruits/Documents/Tropical_Fruits_Spanish2017.pdf

Ascencio, A., Gutiérrez, B., \& Rodríguez, G.B. (2008). Regeneración de plantas de Carica papaya L. a través de la embriogénesis somática en respuesta a la calidad de la luz, agente gelificante y floridcina. Sci Hortic 118: 155-160

Bindu, B. \& Bindu, P. (2017). Tissue culture protocol for in-vitro propagation of papaya (Carica papaya L.). J. Krishi Vigyan 6(1): 205-212. DOI: 10.5958/2349-4433.2017.00081.2

Castro-Gómez, J.C., Cobos-Ruíz, M., Ramírez-Saavedra, R., \& Imán Correa, S. (2012). Aislamiento de ADN genómico de Myrciaria dubia (HBK) Camu Camu apropiado para análisis moleculares Ciencia Amazónica 2(1): 7-16. Doi.org/10.22386/ca.v2i1.19

Chaudhary, K., \& Prakash, J. (2019). Effect of 2,4-D and Picloram on somatic embryogenesis in Carica papaya var. P-7-9. Plant Tissue Cult \& Biotech 29(1): 25-32. DOI: https://doi.org/10.3329/ptcb. v29i1.41976

Dávila, M., \& Castillo, M. (2007). Uso de marcadores moleculares ISSR para inferir las relaciones genéticas y la variabilidad intraespecífico en Agave. Rev Facul Agronom Maracay 106: 93-111. FAO, 2017. FAO (Organización de las Naciones Unidas para la Alimentación y la Agricultura). (2017). Disponible en: http:// www.fao.org/home/es/

González, A., \& Aguirre, X. (2007). Inter Simple Sequence Repeats (ISSRs). En L. E. Eguiarte, V. Souza \& X. Aguirre (Comp.), Ecología 
molecular (pp. 567-571). Ciudad de México: Instituto Nacional de Ecología (Semarnat) y Comisión Nacional para el Conocimiento y Uso de la Biodiversidad (Conabio).

López, A., Ardisana, E., Cornide, M., Coto, O., Vargas, D., Arencibia, A. (2006). Estabilidad genética de plantas de papaya (Carica papaya L., cv Maradol Roja) propagadas in vitro. Revista Innovación tecnológica 12 (3) Disponible en: http://innovacion.lastinas.cu/Vol12No3/No.3.htm

Mirafuentes, F., \& Santamaría, F. (2014). MSXJ, Híbrido de papaya sin carpeloidía para el sureste de México. Revista Mexicana de Ciencias Agrícolas Abril-mayo, 1297-1301

Murashige, T., Skoog, F. (1962). A revised medium for rapid growth and bioassays with tobacco tissue culture. Physiol Plantarum 15: 473-497.

Murray, H., \& Thompson, W. (1980). Rapid isolation of high molecular weight DNA. Nucleilc Acids Res 8: 43214325.

Nei, M. (1972). Genetic distance between populations. Am Nat 106: 283-292.

Olivera-Soto, J. (2009). Micropropagación de papaya (Carica papaya L.) libre de Virus. Instituto Nacional de Innovación Agraria. Perú.

Posada, L. (2005). Aplicaciones de la biotecnología a la propagación de la papaya. Biotec Veg 5: 67-79.

Posada, L., Gómez, K., Gallardo, J., Reyes, M., \& Herrera, L. (2004). Establecimiento in vitro de ápices de plantas del híbrido cubano de papaya IBP 42-99. Biotec Veg 4:153-158.

Rani, V., Raina. S. (1998). Genetic analysis of enhanced-axillary-branching-derived Eucalyptus tereticornis Smith and E. camaldulensis Dehn. plants. Plant Cell Reports 17, 236242. https://doi.org/10.1007/ s002990050385

Setargie, A., Mekbib, F., \& Abraha, E. (2015). In vitro propagation of papaya (Carica papaya L.). World J Agrl Sci 11(2): 84-88. DOI: 10.5829/idosi.wjas.2015.11.2.12619

SIAP (2018). Atlas Agroalimentario 2012-2018. Servicio de Información Agroalimentaria y Pesquera. México.

Solis, M., Olivera, J., \& La Rosa, R. (2011). In vitro propagation of Carica papaya var PTM-331 from apical meristem. Rev Peruana Biotec 18:343-347.

Solórzano, P., Sánchez, N. \& Jiménez, V.M. (2018). Encapsulation affect indirect somatic embryogenesis and regeneration in Carica papaya L. Front Plant Sci 9: art 1769 https://doi.org/10.3389/fpls.2018.01769

Sudha, R., Singh, D., Sankaran, M., Singh, S., Damodaran, V., \& Simachalam, P. (2013). Análisis de la diversidad genética de los genotipos de papaya (Carica papaya L.) en las Islas Andamán utilizando marcadores morfológicos y moleculares. Afr J Agric Res 8: 5187- 5192.

Teixeira-Da Silva, J.A. (2016). Short communication: in vitro response of papaya (Carica papaya) to plant growth regulators. Nusantara Bioscience 8(1): 77-82

Valencia-Sandoval K., Duane-Ávila D., \& Hernández-García T. J. (2017). Estudio del mercado de papaya mexicana: un análisis de su competitividad (2001-2015). Suma de Negocios 8(2017): 131-139.

Vincent, L., Soorianathasundaram K., \& Shivashankara K. S. (2019). Correlation of leaf parameters with incidence of papaya ring spot virus in cultivated papaya and its wild relatives. J Hort Sci 14(2): 130-136.6 https:// www.redalyc.org/articulo.oa?id=5770/577062030006

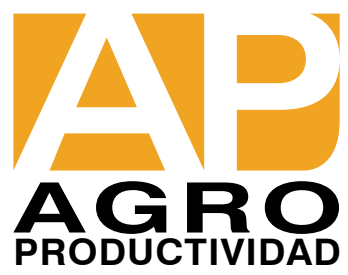

